University for Business and Technology in Kosovo

UBT Knowledge Center

UBT International Conference

2017 UBT International Conference

Oct 28th, 9:00 AM - 10:30 AM

\title{
Bad Design to Kitsch: Examples from Eastern Point of View
}

Çınar Narter

Kadir Has Üniversity, cnarter@khas.edu.tr

Ajhan Bajmaku

University for Business and Technology, ajhan.bajmaku@ubt-uni.net

Follow this and additional works at: https://knowledgecenter.ubt-uni.net/conference

Part of the Architecture Commons

\section{Recommended Citation}

Narter, Çınar and Bajmaku, Ajhan, "Bad Design to Kitsch: Examples from Eastern Point of View" (2017). UBT International Conference. 2.

https://knowledgecenter.ubt-uni.net/conference/2017/all-events/2

This Event is brought to you for free and open access by the Publication and Journals at UBT Knowledge Center. It has been accepted for inclusion in UBT International Conference by an authorized administrator of UBT Knowledge Center. For more information, please contact knowledge.center@ubt-uni.net. 


\title{
Bad Design to Kitsch: Eastern Point of View
}

\author{
Çınar Narter ${ }^{1}$, Ajhan Bajmaku² \\ ${ }^{1}$ Industrial Designer, Kadir Has Üniversity, Industrial Designer, \\ ${ }^{2}$ UBT - Higher Education Institution, Lagjja Kalabria, 10000 p.n., Prishtine, \\ Kosovo \\ ajhan.bajmaku@ubt-uni.net
}

\begin{abstract}
The design case is applied to make a difference in living and to facilitate people's life, from product scale, architectural design to urban scale. A design practice should be able to respond to the user's cognitive and behavioral needs. Today, design solutions that can not respond to these needs are confronted as bad design.

When the habits of consumer society and the low expectations of users are combined, it is inevitable to encounter kitsch phenomenon in design solutions. Kitsch is a term used to refer to banal, rugged, and boring design solutions made with sharps and commercial concerns. It is not easy to define Kitsch exactly, but we can recognize it's representation as soon as we see it. It can also be said that the efficiency of design takes a thin line in terms of application results. The results below this line may be inadequate and bad designs, and those above may be overriding and kitsch. In this study, the examples which show the kitsch design from the bad design are put forward with the examples of product, architecture and urban scale in the eastern countries, especially taking the center of Europe.
\end{abstract}

Keywords: Bad design, Kitsch, Design, Architectural design, Urban design

\section{Introduction}

A large part of mankind has been trying to keep its life in a state trapped in a capitalist system in the last hundred years. The most obvious reflection of the capitalist order can be seen as trying to maintain the continuity of the material return by forming a consumption society (1). The most obvious ending of this is inevitably encountering bad and kitch designs. Products or design at the massive level can be said to be always a part of life as fast and very bad design examples. It can be said that products or designs are needed on a massive scale, bad design examples will always be a part of our life. Bad and kitch designs are confronted by low sensibilities, exhibiting a structure that is far from necessity, particiency and proportion. Trying to design by creating an aesthetic result leads to kitch design (2).

It is necessary to understand good design to describe bad design. There are obvious visual and emotional indicators of good and bad design.

We recognize bad design instantly when we can't tell we're looking at and can't figure out where to go and what to do. At this point, lack of communication comes into play. One of the famous brand guru Neumeier says, "A wealth of information leads to a poverty of attention" (3). "Too much" in the field of design brings with it communication deficiencies and related usage mistakes. Braun chef designer Dieter Rams gives us a banch of keys for define good design in his last book "Less but Better" (4).

Emotional side of bad design is being forced to take in tons of conflicting content at once is jarring, confusing and repulsive. In the other hand, good design organizes information logically 
and gives each piece its own time and space for attention and also w emay say good design often looks attractive. Marty Neumeier gives us an example and said that;

"Good design reflects good virtues (honesty, clarity, courage, substance)... Bad design exhibits laziness, deceit, pettiness and fear." (5)

\section{Communication Losses in Design}

Today, uniformity in design products has created a uniformity that can be described as lack of description and story on products. McCoy, 1990 describes this as the process by which products are transformed into black boxes (6). Technology has created a wide playground in the process of putting original results, especially by interpreting designers' designs. This state of affairs and unbreakable links between form and function have caused extensions in some high-tech products. Competitive market economies and the capitalist system have led to the use of many products that have been lacking in communication between users and products, ignoring the implications, decipherment and loss of use of information on products (7). There must be a way that meaning can exist (8). The form should not be perceived only as a concrete fact (9). The form includes all tangible and abstract factors used for descriptive and descriptive purposes. Sometimes this can be an object, sometimes it can include a word, a sentence, a ceremony, a dance, an image, an image, a photo object or an event (10). By this meaning Bayrakci means;

"The meaning can exist only on a form, but can also be perceived and interpreted through a form" (11)

The product features a structure that maintains its semantic continuity by transforming into the images of collective forms in the society of the society and cultures in which the product is used, form attributes, specific meaning and functional visual equivalents (like: functional interfaces, controls, textures, colors, etc.) (12).

Objects / products show properties that can exist on their own as visual forms and can be used without any other reference. For example, if we think of a vase or Lego building blocks for children, it is not absolutely necessary to provide an explanatory guide for them to be used or understood. They have visual and debaucent qualities that communicate directly with the user, with great effect (13).

Every designed object / product in the product world is inevitably based on and benefit from the existing form language. Innovative and original design products also function to create and expand it by adding new items to the form language. Innovations and changes in designs; Continuity and permanence are the antagonistic features of the product as form language features. The formation of generalizations about style in product design takes place in the form of design (14).

Sudjic, 2008 Due to today's technological acceleration and development, there is a similar erasure and change in dinosaurs in the time-slice object / product world from the first industrial era to the present (15). It can be said that the evolutionary processes experienced in products at the threshold of disappearance as a metaphor are out of control at an incredible rate (16).

For this reason, it can also be stated that the vital cycles of industrial objects that survive today have fallen to the order of months. Each new generation of products in the product world fills up the position of the former as quickly as it creates a situation that does not leave time for improving the relations and communication between users and products (17). This necessitates design consideration in order to ensure that communication channels between products and users are established in the most efficient and efficient manner. Short of the life cycle of products, designers are forced to incorporate design processes into the design process by examining user behaviors, meaning orientations and social social tendencies and behaviors beyond the purely product design field.

The shortness of the product life cycles, meeting new product needs, consumption habits, and so on can be seen as the main causes of poor design and kitch 's entering into our lives. For these 
reasons the product adversely affects user communication, causing the useless products to participate in our lifes.

\section{Communicative Models İn Design}

User conceptualizations, which sometimes affect the product preferences that we see in design circles, are being used in terms of pure sales promotion purposes (18). User conceptualizations addressed are matched to design conceptualizations for this purpose. In other words, the product is created for conceptual sales only. Examples of such behavior are thought to have added value and meaning to such designs.

1. Imitating other areas and products that have no relation with the nature of the product to be designed, using narrative and symbols to call them. As an example: Cat like phone, lip-shaped couch, female body-shaped bottle opener ext.
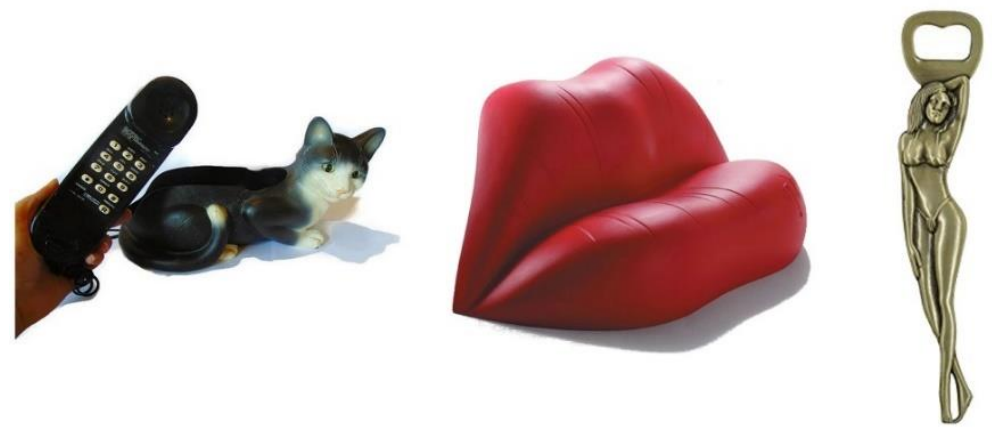

Fig. 1: Cat like phone, lip-shaped couch, female body-shaped bottle opene

2. Adding value symbols from a separate semantic area. As an example: a disfunctional and complex display and control buttons added to show an electronic tool more valuable and professional.
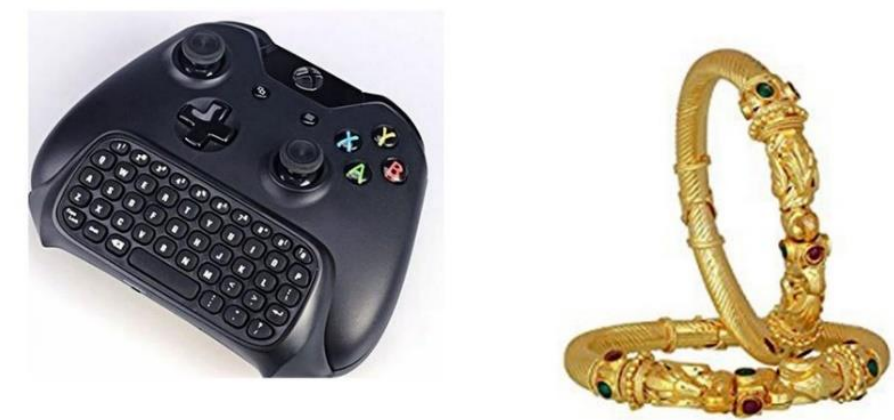

Fig. 2. Disfunctional and complex display and control buttons, jewelsfrom plastic. 
3. While the forms of traditionally valued products are protected, the product is renewed by using cheap material technologies. As an example: to produce recognized jewels from plastic.

4. Evoking well-known people, convincing the users that they can compete with them.

To understand how something in the mind of the user has become meaningful and to try to achieve this through product design to be formed is among the aims of product semantics. Behind these behaviors, the world of icons of lies lies behind the lack of understanding, the alienation and the struggle in vain. certain tools that can be used for conceptualizations in the design process are proposed to prevent such mistakes in the field of design or to prevent deviation from sales promotional and advertising paths. These are (19):

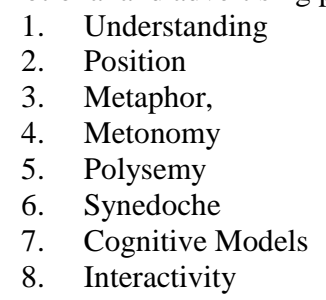

\section{Bad Design to Kitch}

Kitsch is a German term used to classify and express art, which is a duplicate of an existing style. This term is also used to refer to banal, rusty, and boring products made with shabby shades and commercial concerns (20). Most kitsch is the result of individuals following their interests, untrammelled by certian design principles. The designer mixes popülist forms and basic functions to create the desire result. The value judgment that to do so is "inappropriate" is based upon modernist doctrine. Such was the influnece of modernism on design education that it's intellectual framwork became the yardstick against which design was judged "good design" on modernists terms became concidered "good taste" and hence kitsch was regarded "bad taste". Since the 1980's, designers have mixed the emotional and poetic possibilities that emerged from postmodern theory with th common sense aspect of modernism to establish broader bounderies for appropriate aesthetics. While the arbitrary natüre of kitsch is still condemned. Desginers have learned from it's playfulness. The black and white oppsites of kitsch an modernism have been augmneted by a third way where apropriate form can be defined via poetic as well as

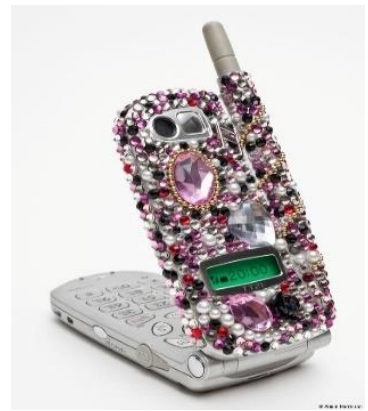

A

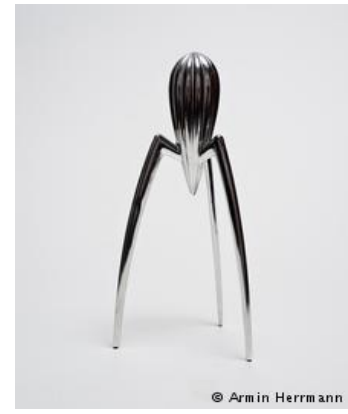

B

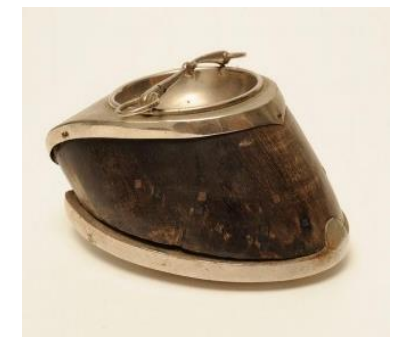

$\mathrm{C}$

Fig. 3: A: Everybody needs a glittering, jewel encrusted cell, B: Functional lies: Philippe Starck's iconic but useless lemon juicer, C: Horse's hoof ash tray 
There is a thinline between bad design and kitsch. The design of this line is not clear, but its use is sometimes overlooked in terms of design, ergonomic and communication problems are considered bad design. However, in the name of design, it seems to be referred to as kitsch designs that lack joke, vulgarity, ordinary, worthless and formless function (21).

The cultural environment and atmosphere that the design serves serve a natural structure that brings together the product quality and the expectation level from the products. the economic status of the society, besides education and cultural structure, determines the design quality and preferences. In this respect, countries in the developing countries class can easily find themselves in bad design and kitsch. Even though the quality expectation level of the users is higher than the products, the economic conditions can be seen as an obstacle to achieving good design. Good quality and good designs are positioned with high price range in capitalist market place. This leads to confusion as the product supports bad design and widespread kitsch specimens in eastern countries.
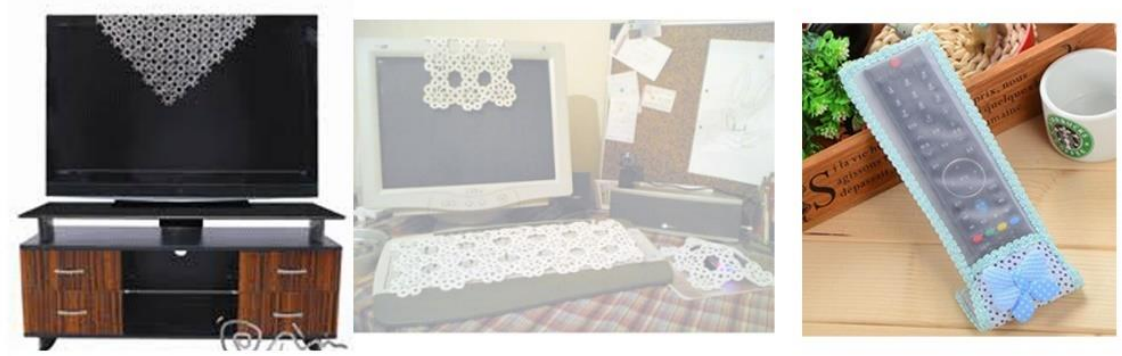

Fig. 4. Kitsch fragments are every where in eastern lifes.
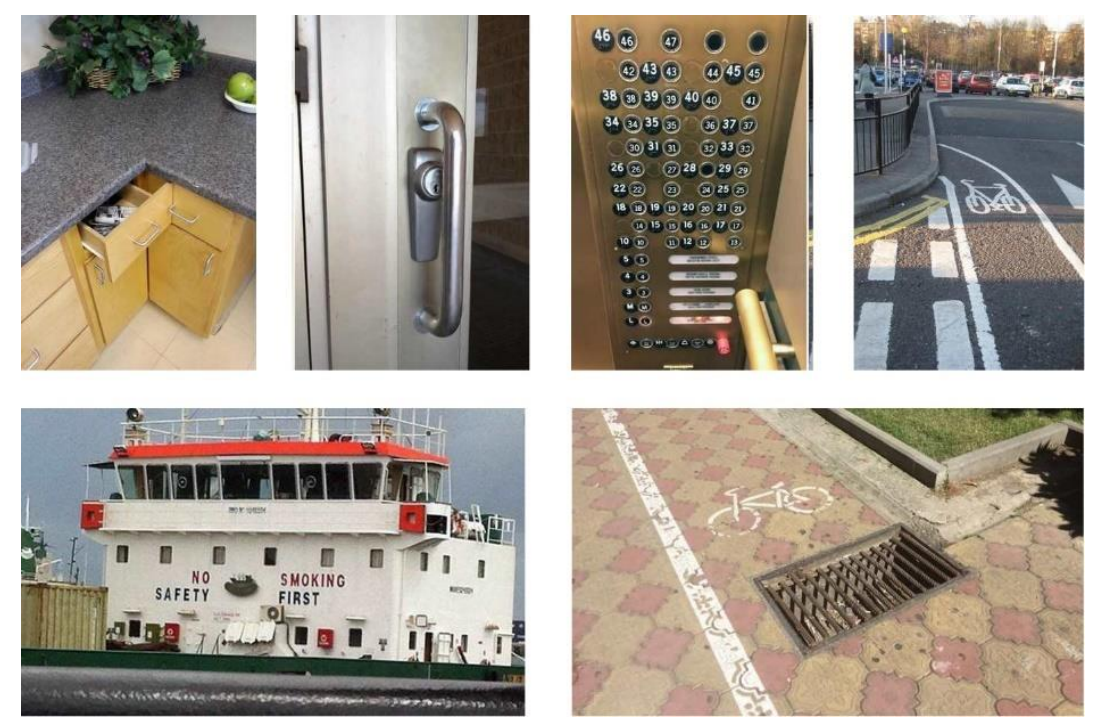

Fig. 5. Bad design examples are in our life. 


\section{Conclusion}

As a result, many bad designs and kitsch have been put forward in the field of design and it is seen that they continue to be put on. Although technology and material science open new horizons in the field of design, it is like a curse that can not get rid of bad design solutions. Today, the need for new products and environmental design to be met so quickly that the design space is also inadequate to meet these needs. In this case there is no decrease in the demand for bad and kitsch design as a result of low education level, low economic situation and insufficient cultural appraisal. High level of user communication at the cultural and societal level must be filled with sincere, clear, honest, simple, rational and not too much design solutions. Trends such as sustainable design, transformable design, environmental design, which are included in contemporary design approaches, can both lead to reaching the design goals mentioned above and also providing solutions for the viewpoint of design for everyone by providing the democratization of the design.

\section{References}

1. Eco, Umberto, "Introduction to Semantics", 1968, Translation: Wilhelm Fing Verlag, Münih, Germany, 1972, p.68.

2. Tarcan Ercüment, "Structure in Industrial Design”, Publisher: msgsü yayınları, 15.08.2001, p.42

3. Neumeier Marty, "The Brand Gap: How to Bridge the Distance Between Business Strategy and Design”, Publisher: New Riders; 2nd edition, August 14, 200, p.48

4. Rams Dieter, “Less But Better”, Publisher: Gestalten; 5 Blg edition, Language: English, ISBN-10: 3899555252, May 20, 2014, p.12

5. www.solvm.com/how-do-you-tell-good-design-from-bad-design

6. McCoy, Michael, "The Post Industrial Designer: Interpreter of Technology",

7. Product Semantics Conference 1989, Editor: S. Vakea, Helsinki, 1990.

8. Blaich, Robert, "Form of Design", Product Semantics Conference 1989, Editor:

9. S. Wakea, Helsinki, 1990, p.47

10. Barthes, Roland, "Semiological Adventure", Translation: M.Rifat, S.Rifat, Yap1

11. Kredi Yayınları, Istanbul, Turkey, 1994, p.25.

12. Bayrakçı, Oğuz, Communication Models in Contemporary Communication Theory, MSGSÜ, Mim. Fak., Endüstri Ürünleri Tasarımı Bölümü, MSGSÜ Matbaası, Ocak 2004

13. Bayrakçı, Oğuz, Communication Models in Contemporary Communication Theory, MSGSÜ, Mim. Fak., Endüstri Ürünleri Tasarımı Bölümü, MSGSÜ Matbaası, Ocak 2004

14. Bayrakçı, Oğuz, Communication Models in Contemporary Communication Theory, MSGSÜ, Mim. Fak., Endüstri Ürünleri Tasarımı Bölümü, MSGSÜ Matbaası, Ocak 2004

15. Owen, Charles. L., \& Chen, Kuohsiang, 1997. "Form Language and Style Description", Design Studies, Vol. 18, No: 3, p.252-254.

16. Heskett, John, “Design”, Translation: Erkan Uzun, Kültür Kitaplığ1 131; Sanat:18, Dost Kitap Evi Yayınları, Agu 2013, Ankara, p.85.

17. Norman, D.A., "Emotional Design: Why We Love Or Hate Everyday Things", New York, NY: A Member of the Perseus Books Group, editors, Zelfstandig leren, 2004, p.110-117. 
18. Sudjic, Deyan, "The Language of Things", Penguin, W.W. Norton \& Company, London, 2008

19. Bayrakçı, Oğuz, Communication Models in Contemporary Communication Theory, MSGSÜ, Mim. Fak., Endüstri Ürünleri Tasarımı Bölümü, MSGSÜ Matbaası, Ocak 2004

20. Sudjic, Deyan, "The Language of Things", Penguin, W.W. Norton \& Company, London, 2008

21. Bayrakçı, Oğuz, Communication Models in Contemporary Communication Theory, MSGSÜ, Mim. Fak., Endüstri Ürünleri Tasarımı Bölümü, MSGSÜ Matbaası, Ocak 2004

22. Krippendorff, Klaus, "Transcending Semiotics: Toward Understanding

23. Design for Understanding Objects and Images", Studies in Design and Advertising, Editor: Susann Vihma, Helsinki, 1992, p.28.

24. https://tr.wikipedia.org/wiki/Kitsch

25. Parsons Tim, "Thinking: Objects: Contemporary Approaches to Product Design”, AVA Publishing SA, 2009, p.72 